\title{
Fiscal decentralizaton in Croatia: problems of fiscal equalization
}

Bajo, Anto; Bronić, Mihaela

Source / Izvornik: Occasional Paper Series, 2005, 9, 1 - 28

Journal article, Published version

Rad u časopisu, Objavljena verzija rada (izdavačev PDF)

https://doi.org/10.3326/ops.25

Permanent link / Trajna poveznica: https:/urn.nsk.hr/urn:nbn:hr:242:816295

Rights / Prava: Attribution-NonCommercial-NoDerivatives 4.0 International/ImenovanjeNekomercijalno-Bez prerada 4.0 međunarodna

Download date / Datum preuzimanja: 2023-04-26

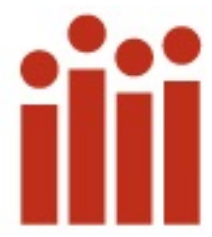

Repository / Repozitorij:

Institute of Public Finance Repository

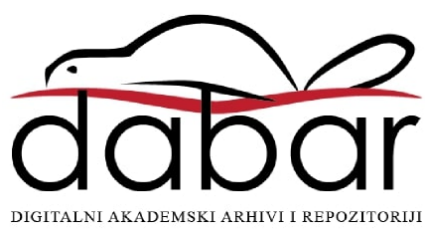


FISCAL DECENTRALISATION IN CROATIA PROBLEMS OF FISCAL EQUALISATION

\author{
Anto Bajo \\ Mihaela Bronić
}

Occasional Paper No. 25

May 2005 


\title{
FISCAL DECENTRALISATION IN CROATIA - PROBLEMS OF FISCAL EQUALISATION*
}

\author{
Anto Bajo \\ Institute of Public Finance, Zagreb \\ bajo@ijf.hr \\ Mihaela Bronić \\ Institute of Public Finance, Zagreb \\ mihaela@ijf.hr
}

\begin{abstract}
In the local government financing system the central government has opted for a central role in the distribution of authorities as well as sources of financing, which can be seen in an increase in the resources that the central government transfers to local government units for the financing of decentralised functions and capital projects. Unluckily, the fiscal equalisation system that relies on the distribution of revenue between the state and local government units and on grants from the central to the local government units is far from effective. The problem inheres in the failure of the mechanism of fiscal equalisation to be based on an accurate assessment of fiscal inequalities or any properly defined fiscal position of the local government units taking into account well founded calculations of fiscal capacities. Because of the poorly regulated mechanism of intergovernmental budget transfers, and particularly because of the lack of quality criteria for the transfer of grants, the implementation of fiscal decentralisation has been slowed and the use of the resources obtained via decentralisation is inefficient. The reasons for this state of affairs should be sought both at the central government and the local government unit level.
\end{abstract}

JEL Classification: H61, H70

Key words: fiscal decentralisation, fiscal equalisation, grants, regional inequality

"This article is published in Croatian in the journal "Financijska teorija i praksa", 28(4), 2004, pp. 445-469, and is downloadable from: http://www.ijf.hr/financijska_praksa/PDF-2004/4-04/bajo_bronic.pdf. 


\section{INTRODUCTION}

The main thesis of this paper is that the model of fiscal decentralisation in Croatia is not effective and that a hitch has occurred in the effective use of resources that the central government has transferred to the local government units. The reasons for this ineffectiveness lie in the poorly defined model of fiscal equalisation that is based on central government grant allocation criteria defined with insufficient clarity and in the complicated system of tax sharing.

The first part of the work shows the size of local government units in Croatia, the second part explains the distribution of authorities and sources of financing between central government and local government units, the third sets out the degree of fiscal autonomy according to size and structure of the revenues and expenditures of local government units. In part four the model of fiscal equalisation is explained with a special emphasis on the assessment of the degree of fiscal regional inequalities. In part five the main problems in the implementation of fiscal decentralisation are stated and recommendations for their resolution given, while part six is the conclusion.

\section{THE SIZE OF LOCAL GOVERNMENT UNITS}

The Croatian system of local government unit financing can be divided into two periods; the first, from 1994 to 2001, and the second, from 2001 on. In the first period the system of local government financing was centralised and the local government units' autonomy in collecting revenue and allocating their expenditure was restricted. This period is marked by the passing of legal solutions in which the authorities for financing were settled, as was the distribution between central and local government of fiscal and administrative spheres of competence. In Croatia there were then three levels of government: central government, the counties, and the local government units (municipalities and cities). As well as having the status of units of local self-government, the counties were also administrative units of the central government. Since 2001 administrative and self-government functions can be carried out by all local government units, and the authorities and competence of local government units are more clearly defined.

A good indicator of the dynamics of change in these two periods is represented by the size of the local government units, that is, the expenditure of the local government units as a share of GDP and of the total expenditure of general government.

Table 1 The budgets of local government units as percentage of the general government budget and of GDP from 1999 to 2003

\begin{tabular}{|c|c|c|c|c|c|}
\hline $\begin{array}{l}\text { 1.The revenue/expenditure of local government units as } \\
\text { percentage of the revenue/expenditure of general government }\end{array}$ & 1999 & 2000 & 2001 & 2002 & 2003 \\
\hline Revenue & 11.2 & 12.6 & 12.9 & 15.1 & 16.1 \\
\hline Expenditure & 11.1 & 11.8 & 12.6 & 14.3 & 15.2 \\
\hline \multicolumn{6}{|l|}{$\begin{array}{l}\text { 2. Revenue/expenditure of local government as percentage of } \\
\text { GDP }\end{array}$} \\
\hline Revenue & 5.9 & 6.2 & 6.0 & 7.0 & 7.5 \\
\hline Expenditure & 6.1 & 6.4 & 6.2 & 7.0 & 7.5 \\
\hline 3. General government expenditure as $\%$ of GDP & 54.8 & 54.0 & 49.1 & 48.8 & 49.4 \\
\hline
\end{tabular}

Source: Finance Ministry of Republic of Croatia, 2004. 
The size of the local government units, which is to say the expenditure of local government units as a percentage of GDP, right up to 2001 ranged in the area of $6.2 \%$. From 2001, when decentralisation started, this percentage became larger. Thus the expenditure of local government units as percentage of GDP in 2003 was at the $7.5 \%$. The size of revenue follows the same trend.

The expenditure of local government units as percentage of general government rose from $11 \%$ in 1999 to $15 \%$ in 2003 . The positive financial trends are particularly clearly expressed on the revenue side. Thus the revenue of local government units in 1999 came to about $11 \%$ but in 2004 over $16 \%$ of the revenue of the general government budget.

In spite of the favourable financial position the question to what extent local government units are fiscally autonomous remains open, that is, to what extent have responsibilities and sources of funds been transferred to the competence of local government units?

\section{DISTRIBUTION OF RESPONSIBILITIES AND SOURCES OF FUNDS}

\subsection{Distribution of responsibilities (competences)}

Cities and municipalities in their self-governing area of competence carry out matters of local importance through which the needs of citizens are met directly and which are not by the Constitution or law assigned to bodies of central government. Here they carry out the following assignments: housing, physical and town planning, communal economy matters, child care, welfare, primary health care, pre-school and elementary school education, culture, physical culture and sport, protection and improvement of the environment and civilian protection and fire protection. The county carries out matters of regional significance, particularly matters related to: education, health care, physical and town planning, economic development, traffic and the transportation infrastructure, and the planning and development of the network of educational, healthcare, welfare and cultural establishments.

All municipalities and cities may also carry out matters from the self-government jurisdiction of the county in their own area, if they provide funds for the financing of them. Although the responsibilities and jurisdictions of local government units are laid down, nevertheless local government units do not have total fiscal autonomy in the financing of all their expenditures because revenue sharing and central government grants are earmarked for financing decentralized functions and capital investment.

Table 2 Distribution of functions according to levels of government

\begin{tabular}{|c|c|c|c|c|c|}
\hline & & Central government & Municipalities & Cities & Counties \\
\hline 1. & General public services & $x$ & $x$ & $x$ & $x$ \\
\hline 2. & Defence & $x$ & & & \\
\hline 3. & Public order and security & $x$ & $x$ & $x$ & \\
\hline 4. & Education & $x$ & $x$ & $x$ & $x$ \\
\hline 4.1. & preschool & & $x$ & $x$ & \\
\hline 4.2. & elementary & $x$ & $x$ & $x$ & $x$ \\
\hline 4.3. & secondary & $x$ & & & $x$ \\
\hline 4.4. & tertiary & $x$ & & & \\
\hline 5. & Health care & $x$ & & & $x$ \\
\hline
\end{tabular}




\begin{tabular}{|c|c|c|c|c|c|}
\hline 6. & Social security and welfare & $x$ & $\mathrm{X}$ & $\mathrm{X}$ & $x$ \\
\hline 7. & $\begin{array}{l}\text { Housing and communal economy } \\
\text { matters and services }\end{array}$ & & $\mathrm{X}$ & $X$ & \\
\hline 8. & Recreation, culture and religion & & $\mathrm{X}$ & $x$ & \\
\hline 9. & Agriculture, forestry, hunting, fishing & $x$ & & & $x$ \\
\hline 10. & Mining, industry, construction & $\mathrm{X}$ & $x$ & $x$ & $x$ \\
\hline 11. & Traffic and communications & $x$ & $x$ & $\mathrm{X}$ & $x$ \\
\hline 11.1. & Road transport & $x$ & $x$ & $x$ & $x$ \\
\hline 11.2. & Rail transport & $x$ & & & \\
\hline 11.3. & Air transport & $x$ & & & \\
\hline 12. & Other economic matters and services & $x$ & $x$ & $x$ & $x$ \\
\hline
\end{tabular}

Source: Ott and Bajo, 2001.

Note: Housing and communal economy services: drinking water supply, drainage and treatment of sewage, gas and heat supply, public transport, cleaning, deposition of waste, maintenance of public areas, maintaining of roads, retail market, cemetery and crematorium maintenance, chimney sweeping, street light (management, maintenance of facilities and devices). Welfare responsibilities include payment of financial benefits and provision of services (i.e. homes for the elderly, child protection etc.).

Local government units finance a significant part of their expenditures in collaboration with central government, which provides grants from the central government (national) budget via the Ministry of Finance or the competent ministries. Greater local government unit autonomy can be found in connection with the performance of the communal economy activity, preschool education and cultural, sporting and religious activities.

From 2001 in the fiscal decentralisation programme the central government transferred responsibility for financing education, health care, welfare and fire departments to the local government units. Central government transferred authorities for financing only a part of the costs of health care and education (that is, for the material costs and expenditure for the procurement on non-financial assets) and full costs (with salaries) to the local government units that took responsibilities for financing welfare ${ }^{1}$ and fire departments. Financing of the decentralised functions was taken on by local government units with the greatest fiscal capacities. Of the 570 local government units, 53 of them (20 counties, the city of Zagreb and 23 municipalities and cities) assumed the obligation of financing the decentralised functions. In addition, from 2002 the financing of the fire departments was taken on by 83 local government units (municipalities and cities). It is interesting that the total budget of the 53 local government units that assumed the financing of the decentralised functions constitutes about $70 \%$ of the consolidated budget of all local government units.

\subsection{Distribution of sources of financing}

Fiscal autonomy means the capacity of local government units independently to fix the bases and rates of taxation as well as non-taxation revenue.

Local government units in Croatia are not autonomous in the determination of base and rates of tax revenue. This can be seen from the following table.

\footnotetext{
${ }^{1}$ Welfare responsibilities include payment of financial benefits and provision of services (i.e. homes for the elderly, child protection etc.)
} 
Table 3 Division of authorities for setting rates of individual taxes

\begin{tabular}{|l|c|c|c|}
\hline & $\begin{array}{c}\text { Central } \\
\text { government }\end{array}$ & $\begin{array}{c}\text { Local } \\
\text { government, } \\
\text { Autonomously }\end{array}$ & $\begin{array}{c}\text { Local } \\
\text { government, } \\
\text { Restrictedly }\end{array}$ \\
\hline JOINT TAXES & $\mathrm{X}$ & & \\
\hline Income tax & $\mathrm{X}$ & & \\
\hline Profit tax & $\mathrm{X}$ & & \\
\hline Real estate sales tax & $\mathrm{X}$ & & \\
\hline COUNTY TAXES & $\mathrm{X}$ & & \\
\hline Tax on gifts and inheritances & $\mathrm{X}$ & & \\
\hline Tax on road motor vehicles & $\mathrm{X}$ & & \\
\hline Tax on vessels & & & \\
\hline Tax on coin operated machines for amusement & & & \\
\hline MUNICIPAL AND CITY TAXES & & & \\
\hline Consumption tax & & & $\mathrm{X}$ \\
\hline Second home tax & & & $\mathrm{X}$ \\
\hline Use of public land tax & & & $\mathrm{X}$ \\
\hline Tax on uncultivated but cultivable agricultural land & & & \\
\hline Tax on unused entrepreneurial real estate & & & \\
\hline Tax on undeveloped building land & & & \\
\hline Tax on trade name or corporate name & & & \\
\hline Surtax on income tax & & & \\
\hline
\end{tabular}

To a relatively small extent the local government units can set the rates of local tax revenue. The rates of joint taxes (which are divided between municipality, city, county and central government) and of county taxes are completely determined by central government. The rates of municipal and city taxes are on the whole determined by the municipal or city authority, but within the framework of the limits set by central government. Only for one kind of municipal or city tax (that on the use of public land) does local government determine the tax rate with complete autonomy.

Local government units autonomously determine the rates of surtax on income tax within the framework of a limit (the maximum possible rate of surtax) set by the central government. Thus up to 2001, surtax could be introduced only by cities with populations of more than 40,000 . The maximum rate of surtax that they could impose was $30 \%$ (the city of Zagreb up to 60\%) of taxable income. From 2001 on all local government units could introduce surtax, and an upper and a lower limit for the surtax they could introduce was fixed. The current maximum rates of surtax are: $10 \%$ for municipalities, $12 \%$ for cities up to the 30.000 citizens and $15 \%$ for cities with more than 30.000 citizens (the city Zagreb up to $30 \%$ ). Surtax revenue goes to the city or municipality in the area of which the taxpayer is domiciled. Up to 2001,12 local government units had introduced surtax; from 2001 to 2003 as many as 213 local government units (61 cities and 152 municipalities) brought in surtax.

Tax revenue sharing (joint taxes). The local government unit financing system is based to a great extent on the mechanism of sharing tax revenue between central and local government. From 1994 to 2001 
central government ceded to the counties, municipalities and cities a share in the tax revenue collected in their areas.

Table 4 Tax sharing between central government and local government units from 1994 to 2001, in \%

\begin{tabular}{|l|r|r|r|r|}
\hline Tax on: & Central government & Counties & Municipalities and cities & Zagreb \\
\hline income & 60 & 8 & 32 & - \\
\hline income, (in the City of Zagreb) & 50 & 5 & - & 45 \\
\hline profit & 70 & 10 & 20 & - \\
\hline profit, (in the City of Zagreb) & 70 & - & 60 & 30 \\
\hline real estate sales & 40 & - & - \\
\hline
\end{tabular}

Because of this distribution, income tax, profit tax and real estate transfer tax became the most productive sources of revenue of local government units.

Table 5 Tax sharing between central and local government in 2003, in \%

\begin{tabular}{|l|r|r|r|r|r|r|}
\hline Tax on: & $\begin{array}{r}\text { Central } \\
\text { government }\end{array}$ & Counties & $\begin{array}{r}\text { Municipalities } \\
\text { and cities }\end{array}$ & $\begin{array}{r}\text { Decentralised } \\
\text { functions }\end{array}$ & $\begin{array}{r}\text { Fire } \\
\text { departments }\end{array}$ & $\begin{array}{r}\text { Equalisation } \\
\text { Fund }\end{array}$ \\
\hline income & 25.6 & 10 & 34 & 9.4 & 1 & 21 \\
\hline $\begin{array}{l}\text { income, (in the City of } \\
\text { Zagreb) }\end{array}$ & 25.6 & & 47 & 9.4 & 1 & 21 \\
\hline profit & 70 & 10 & 20 & - & - & - \\
\hline real estate sales & 40 & - & 60 & - & - & - \\
\hline
\end{tabular}

For local government units that took on the financing of the decentralised functions, since 2001 central government has provided a larger share of income tax. Apart from that, central government provided additional resources from the Equalisation Fund, as it is called, for local government units that took on the financing of the decentralised functions but are not able to finance them from the tax they obtained from income tax. This Equalisation Fund is in effect part of income tax that central government cedes to local government units with low fiscal capacities for the financing of the decentralised functions. We should mention that only 300 of the total 570 local government units take part in the filling of this fund. Other (270) local government that have a special status in financing (areas of special national concern, hill and mounting areas and insular local government) didn't take part in filling this fund. For these local government units central government transferred all amount of income tax collected on its areas.

Non-tax revenue is the autonomous revenue of local government units the purpose of which is set in advance. Local government units independently set the rates of non-tax revenue and independently carry out the collection of this revenue. The main non-tax revenue consists of municipal economy charges and contributions with which local government units finance the construction and maintenance of the utility infrastructure. The communal economy charge and contributions are also the largest revenue of local government units.

Capital revenue is obtained by local government units by the sale of assets and the privatisation of the local utility firms. It is mainly municipalities and cities that generate capital revenue. Up to 2000 most local government units had made drawn up an assets balance sheet. Thanks to this list, most of the local government units stepped up such sales and increased their revenue from the sale of assets. 


\section{THE FISCAL AUTONOMY OF LOCAL GOVERNMENT UNITS}

The fiscal autonomy of local government units in collecting their own revenue is relatively low. The most productive tax revenue is shared with central government, which at the same time determines the tax base and the rates of these taxes. The local government units obtain the least amount of revenue from their own taxes. Local government units have autonomy in the use of non-tax revenue and just a small part of their own tax revenue. It is also dubious to what extent they are autonomous in the use of non-tax revenue. For almost all the non-tax revenue of local government units has a set use for which it can exclusively be employed. Thus the most important non-tax revenue (municipal economy charges and contributions) must be used for the financing of the utility or communal economy infrastructure. Nevertheless, let us look at the figures concerning the realisation of the budgets of local government units from 1999 to 2003.

\subsection{Autonomy in setting revenue}

The revenue of local government units increased importantly from 2001, thanks to the beginnings of fiscal decentralisation or the increased share of local government units in income tax.

Table 6 The structure of total revenue of local government units from 1999 to 2003, in million kuna and in $\%$

\begin{tabular}{|lrrrrr|}
\hline In million kuna & 1999 & 2000 & 2001 & 2002 & 2003 \\
\hline Tax revenue & 4,624 & 4,995 & 5,273 & 7,066 & 8,380 \\
Grants & 644 & 698 & 961 & 1,237 & 1,504 \\
Non-tax revenue & 2,555 & 2,980 & 3,043 & 3,484 & 3,890 \\
Capital revenue & 555 & 736 & 684 & 704 & 710 \\
\hline Total revenue & 8,378 & 9,409 & 9,961 & 12,491 & 14,484 \\
\hline Revenue as \% of total revenue & & & & & \\
\hline Tax revenue & 55 & 53 & 53 & 57 & 58 \\
Grants & 8 & 7 & 10 & 10 & 10 \\
Non-tax revenue & 30 & 32 & 31 & 28 & 27 \\
Capital revenue & 7 & 8 & 7 & 6 & 5 \\
\hline Total revenue & 100 & 100 & 100 & 100 & 100 \\
\hline
\end{tabular}

Source: Finance Ministry of Republic of Croatia, 2004.

Total revenue of local government units increased from the ca 8 billion kuna in 1999 to about 10 billion kuna in 2001. With the beginning of the fiscal decentralisation process in 2001, the central government to a greater extent ceded part of the revenue to local government units through income tax and at the same time raised the level of grants. For this reason, revenue increased from 10 billion in 2001 to over 14 billion kuna in 2003. The structure of this is dominated by tax revenue, the share of which increased from $53 \%$ in 2001 to $58 \%$ of the entire revenue of local government units in 2003 . At the same time the proportion of non-tax revenues in the budgets of local government units decreased from 31 to $27 \%$ in 2003, and resources from central government budget grants comprised $10 \%$ of the revenue of local government units. 
Table 7 Structure of tax revenue from 1999 to 2004, in million kuna

\begin{tabular}{|l|r|r|r|r|r|}
\hline & 1999 & 2000 & 2001 & 2002 & 2003 \\
\hline Income tax and surtax & 2,967 & 3,177 & 3,625 & 5,068 & 6,119 \\
\hline of which: surtax on income tax & na & na & na & 712 & 783 \\
\hline Profit tax & 975 & 1,095 & 892 & 1,171 & 1,400 \\
\hline Property tax & 513 & 540 & 592 & 524 & 527 \\
\hline Goods and services tax & 158 & 174 & 162 & 289 & 333 \\
\hline Other taxes & 11 & 9 & 1 & 15 & 1 \\
\hline Total & 4,624 & 4,995 & 5,273 & 7,066 & 8,381 \\
\hline
\end{tabular}

Source: Finance Ministry of Republic of Croatia, 2004.

It is mainly the taxes local government units share with the central government according to set percentages that dominate the structure of tax revenue. Primarily this means income tax, profit tax and property tax. Income tax and surtax increased from 3.6 billion in 2001 to about 6.1 billion in 2003. Most of this increase is the result of a larger share of income tax revenue for local government units that took on the obligation to finance the decentralised functions. On the other had a large number of local government units took advantage of the possibility of introducing surtax, which additionally increased their total budgetary revenue. It should be pointed out that profit tax went up from 892 million kuna in 2001 to 1.4 billion kuna in 2003. Property tax is gradually bringing decreased yields. Real estate tax, which the local government units share with central government, is predominant in the structure of this tax. Tax on goods and services and other taxes make up only minor items in the budgets of local government units.

\subsection{Autonomy in setting expenditure}

Local government units have restricted autonomy in determining the purpose of resources. This is shown by the structure of budgetary expenditure of local government units in which material and labour costs are dominant.

Table 8 Expenditure of local government units from 1999 to 2003, in million kuna

\begin{tabular}{|l|r|r|r|r|r|}
\hline & 1999 & 2000 & 2001 & 2002 & 2003 \\
\hline 1.Current expenditure & 6,064 & 6,769 & 8,237 & 9,366 & 10,875 \\
\hline 1.1. for labour & 1,705 & 1,874 & 1,356 & 2,029 & 2,257 \\
\hline 1.2. for goods and services & 2,247 & 2,538 & 2,475 & 3,703 & 4,244 \\
\hline 1.3. financial expenditures & 134 & 143 & 203 & 232 & 474 \\
\hline 1.4. subsidies and other current transfers & 1,978 & 2,214 & 4,203 & 3,402 & 3,900 \\
\hline 2. Capital expenditure & 2,647 & 2,939 & 2,017 & 2,358 & 3,540 \\
\hline Total (1+2) & 8,711 & 9,708 & 10,254 & 11,724 & 14,415 \\
\hline
\end{tabular}

Source: Finance Ministry of Republic of Croatia, 2004.

Material and labour expenses of local government units increased because of the decentralisation of the financing of local government units. A relatively large share of the budgets of local government units is related to capital expenditure, which increased from 2 billion kuna in 2001 to 3.5 billion kuna in 2003. 
Table 9 Expenditure according to the functions of local government unit in 2002 and 2003, in million kuna

\begin{tabular}{|r|l|r|r|}
\hline & & 2002 & 2003 \\
\hline 01 & General public services & 2,271 & 2,672 \\
\hline 02 & Defence $^{*}$ & 1 & 2 \\
\hline 03 & Public order and security** $^{* *}$ & 338 & 490 \\
\hline 05 & Economic affairs & 1,898 & 2,364 \\
\hline 06 & Housing improvement services & 436 & 562 \\
\hline 07 & Health care & 2,211 & 3,111 \\
\hline 08 & Recreation, culture and religion & 485 & 575 \\
\hline 09 & Education & 1,321 & 1,600 \\
\hline 10 & Welfare & 1,997 & 2,539 \\
\hline & Total & 573 & 671 \\
\hline
\end{tabular}

Source: Finance Ministry of Republic of Croatia, 2004.

Note: *Expenditure for civilian protection ** This expenditure relates to financing the fire departments

Most of the expenditure of local government units according to functions is related to the communal economy activities, and then come general public (administrative) services, and education. The items relating to the decentralised functions, particularly health care and welfare have increased considerably. We should mention that expenditure for public order and security is related to the financing of the fire departments that some of the local government units have assumed jurisdiction for since 2002.

\section{FISCAL EQUALISATION MODEL}

The system of fiscal equalisation through which the central government endeavours to even up the development of inadequately developed regions in Croatia is based upon two main mechanisms: 1 vertical - revenue sharing and 2: horizontal - current and capital grants.

The efforts of central government to help the reconstruction and development of areas damaged in the war through the fiscal equalisation system are quite clear. In addition to this, since 2001, the central government has expanded the scope of local government units that have special status in the financing system and that it stimulates through tax exemptions and a number of tax incentives. The distribution of tax revenue is used by central government to palliate the fiscal unevenness that exists among local government units and for the financing of the decentralised functions of local government units that have assumed responsibility for them.

Central government tries to equalize fiscal capacity disparities between the local government units by grants. Two types of grants are used: general current grants and capital investment grants. Until 2001, the Law on financing of local government units prescribed grants allocation criteria. Since 2001, Grants allocation criteria were more detailed and defined yearly in budget execution law. Central government (the Ministry of finance) defines criteria for grants allocations. Additionally, counties are also obliged to set up criteria for allocation of grants to the municipalities and cities on their area.

Before we explain the system of fiscal equalisation we shall analyse the degree of fiscal inequalities among the counties in 2001. 


\subsection{Regional fiscal inequalities}

We explain the regional differences among local government units in Croatia using the example of regional (county) budgetary revenue and expenditure, and GDP in 2001. The objective is to determine the justification of the allocation of grants from central government to local government units and to determine whether these grants are based on well-chosen criteria. The degree of regional inequality is analysed pursuant to four kinds of comparison:

1. the ability to cover current expenditure with current revenue and total grants from central government as a percentage of regional GDP,

2. per capita revenue and grants,

3. regional grants from central government per capita and regional GDP and

4. tax and non-tax revenue and regional GDP.

\subsubsection{The abilities of local government units to cover current expenditure with current revenue and central government grants as percentage of regional GDP}

As shown by Fig. 1, through a comparison of the degree of financial autonomy (ability of countries to finance current expenditure with current revenue) and the amount of grants from central government (as percentage of GDP) we have endeavoured to find out if central government in the allocation of grants has made a good assessment of the financial positions of the counties. A 1.0 cover means that the county is capable of covering current expenditure with its current revenue (before grants and capital revenue are counted).

Figure 1 Comparison of financial autonomy of local government units and grants allocated in 2001

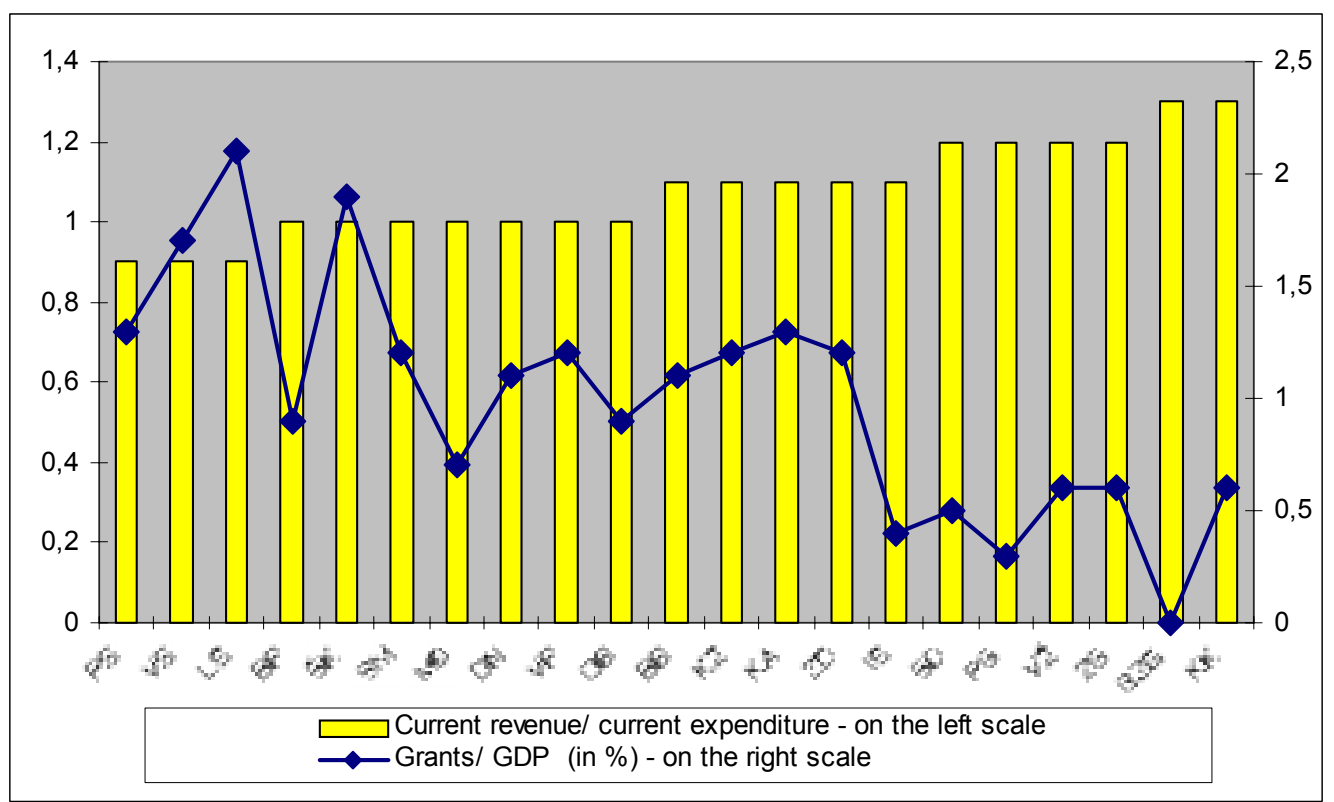

Note: see abbreviations in table 15.

We found out that most counties can finance current expenditure with current revenue. In 2001, only six counties were not capable of this. However, these six too covered $90 \%$ of current expenditure with current revenue. Most of the counties were independently capable of financing current expenditure with current revenue and major grants from central government were not necessary for financing current expenditure. 
However, all the counties, apart from the city of Zagreb, did obtain grants (capital and current) from central government, many of them in rather large amounts. Central government clearly did not pay attention to the degree of fiscal inequality and allocated grants to counties with high fiscal capacities.

\subsubsection{Counties' own revenue and total grants}

The distribution of own revenue and central government grants per capita per county (Fig. 2) shows where the grants were well directed, i.e., allocated to local government units with low fiscal capacities.

Figure 2 Distribution of own revenue and grant per county in 2001

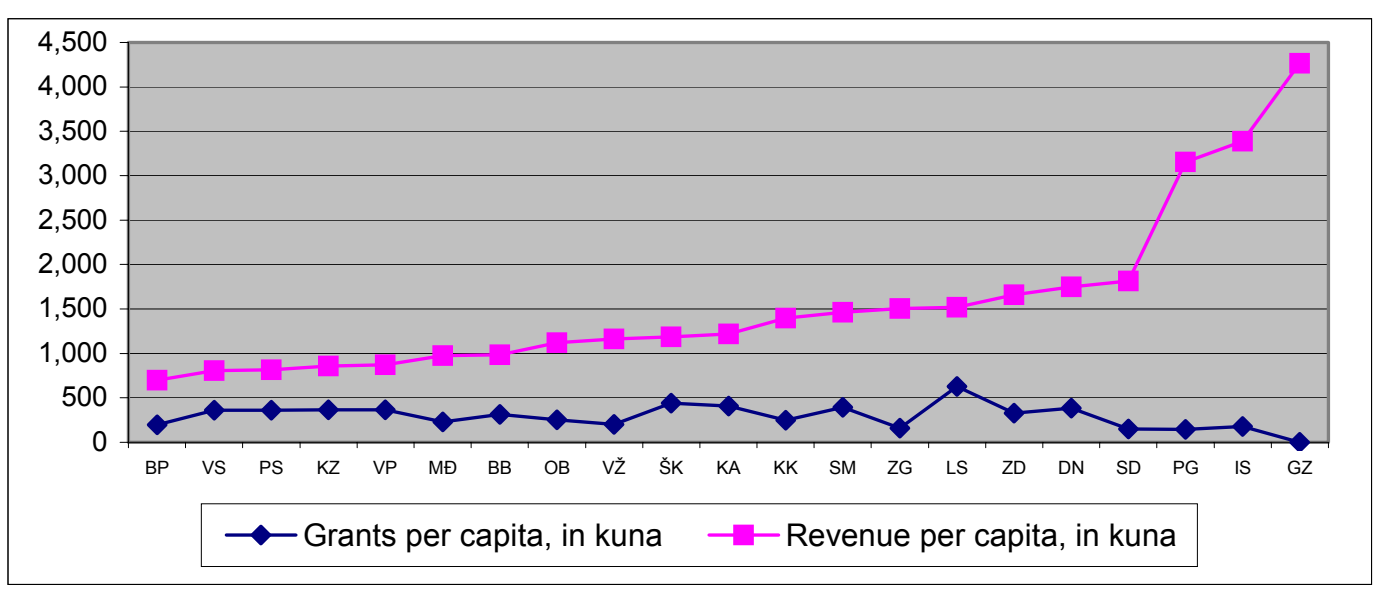

Note: see abbreviations in table 15.

Three counties (the city of Zagreb, the Primorsko-goranska and Istria counties) had much greater per capita revenue than the other counties. The law on financing local government units says that the city of Zagreb has too high a fiscal capacity to receive any current general grants from central government.

In 2001 the counties (not including Zagreb) had an average 1,500 kuna own per capita revenue. Unfortunately, central government, through the system of grant allocation, did not in any very significant way do anything to help counties with a per capita revenue of less than 1,500 kuna. Clearly, all counties, irrespective of the size of their per capita revenue, obtained an equal per capita grant (about 260 kuna). An exception is the Ličko-senjska County, which got triple the average grant. Šibenik and Karlovac counties also obtained major amounts of grants. Interestingly, however, not one of these three counties belongs to the group of counties with the least per capita revenue of its own. Thus not even according to the own per capita revenue criterion are central government grants distributed evenly across the counties.

\subsubsection{Distribution of grants and GDP per county}

The distribution of GDP per region is one of the most important criteria that central government ought to take into consideration in allotting its grants. A comparison of total regional grants per county and regional GDP (Fig. 3) should show if there is a negative correlation between the grants allocated to counties and county GDP. We start off from the hypothesis that grants should be allocated to those counties (local government units) with lower per capita GDP. 
Figure 3 GDP and grants per capita in the counties in 2001

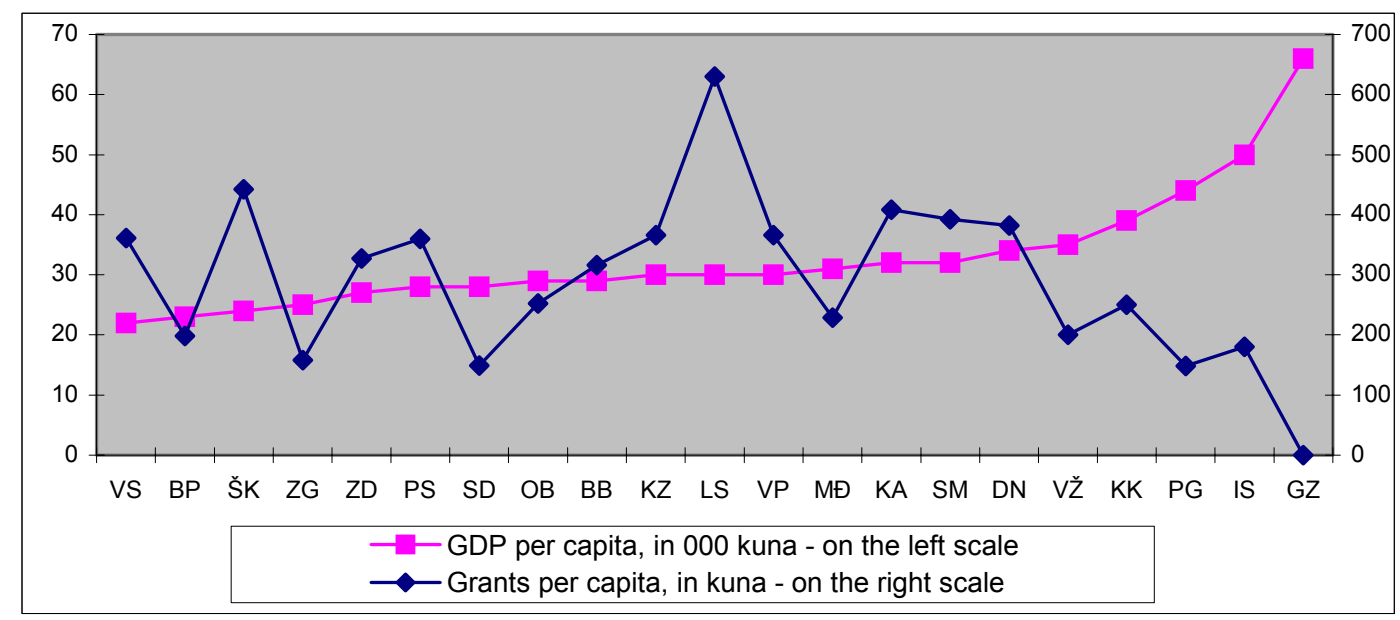

Note: see abbreviations in table 15.

We found out that there was reason for the allocation of grants to 12 counties. On the other hand 9 counties did not need to be given central government grants. Three counties (Karlovac, Sisak and Dubrovnik), with an above-average regional per capita GDP obtained higher per capita grants than the county with the smallest per capita GDP (Vukovar). Three counties (Slavonski Brod, Zagreb and Split) obtained relatively lower per capita grants as compared with other counties with similar GDP. It is interesting that Ličko-senjska County has an almost average per capita GDP ${ }^{2}$ and yet obtained by far the highest per capita grant.

\subsubsection{Tax and non-tax burden and regional (county) per capita GDP}

The fourth indicator of financial inequality that should be taken into account during the allocation of and determination of the criteria for grants to local government units is the distribution of the tax and non-tax burden (Fig. 4). It can be expected that a county with higher per capita GDP will also have collected more tax and non-tax revenue. However, in 2001 this was not the case.

Figure 4 Comparison of tax and non-tax burden of counties and county per capita GDP in 2001

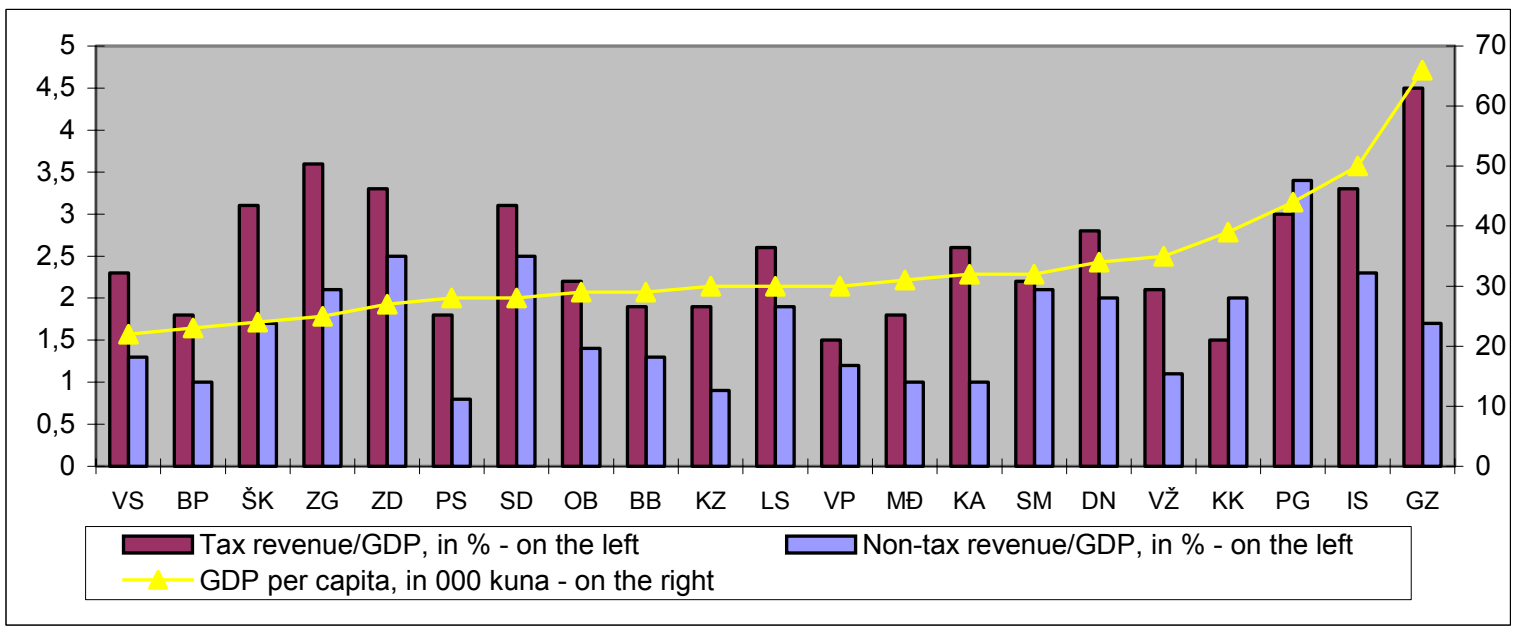

Note: see abbreviations in table 15.

\footnotetext{
${ }^{2}$ The average regional GDP not including the city of Zagreb was about 30,000 kuna.
} 
Many counties with relatively high GDP collect much lower revenue than counties that have smaller GDP. Thus for example, the city of Zagreb, which has by far the highest per capita GDP, collected the least nontax revenue per capita. The case is the same with counties that have above-average per capita GDP and collected relatively small tax and non-tax revenue per capita (Varaždin, Virovitica, Međimurje, Koprivnica). The counties with a relatively low GDP per capita (Šibenik, Zagreb and Zadar) collected above average tax and non-tax per capita revenue, and more than counties with a higher GDP (like Varaždin and Koprivnica counties). It should be pointed out that it is the Tax Administration that collects tax revenues, and the local government units collect non-tax revenue independently. The effort of local government units to collect non-tax revenue is rather low and it can be seen that local government units with lower fiscal capacities collect more non-tax revenue per capita than local government units with higher fiscal capacities.

According to an analysis of four indicators of regional differences, then, we can conclude that the grant allocation system does not pay attention to the degree of regional fiscal inequality. For this reason it is necessary to change the criteria for the allocation of grants, with greater respect being paid to differences in the fiscal capacity of local government units. For a higher quality determination of the criteria for the allocation of grants, it is necessary to investigate the financial position of each municipality and city in the area of a county. As well as regional GDP, in the calculation and establishment of the difference between local government units, it is necessary to take into account other indicators as well that reveal differences in the revenue and real need for expenditure of all cities and municipalities in the area of a county.

\subsection{The fiscal equalisation system}

\subsubsection{Vertical fiscal equalisation}

\subsubsection{Current special purpose grants - equalisation grants for decentralised functions}

From 2001, central government provided for the 53 local government units that had taken on the obligation to finance the decentralised functions an additional share in income tax (see Table 5). Thus local government units that took on the financing of all the decentralised functions were able to increase their share in income tax by $10 \%$. If they took on the financing of only some of the functions, then this share was fixed in the following manner:

Table 10 Local government units' additional share in income tax for decentralised functions, in \%

\begin{tabular}{|c|r|r|r|r|r|r|}
\hline $\begin{array}{c}\text { Decentralised } \\
\text { functions }\end{array}$ & $\begin{array}{r}\text { Elementary } \\
\text { education }\end{array}$ & $\begin{array}{r}\text { Secondary } \\
\text { education }\end{array}$ & Health Care & Welfare & $\begin{array}{r}\text { Fire } \\
\text { Departments }\end{array}$ & Total \\
\hline$\%$ & 2.9 & 2 & 2 & 2.5 & 1 & 10.4 \\
\hline
\end{tabular}

Source: Finance Ministry of Republic of Croatia, 2004.

The following table shows the financing of the decentralised functions with an additional share of local government units in income tax and resources from the Equalisation Fund, as it is known. The distributions of equalisation fund adjust disparities in the value of the additional income tax share. The total of the two sources were added up to the expenditure norms (minimal financial standards) set for the decentralised functions. 
Table 11 Financing of decentralised functions of local government units from income tax and the Equalisation Fund in 2002 and 2003

\begin{tabular}{|c|c|c|c|c|c|c|c|}
\hline & & \multicolumn{3}{|c|}{2002.} & \multicolumn{3}{|c|}{2003.} \\
\hline & Decentralised functions & $\begin{array}{r}\text { Counties } \\
\text { and Zagreb }\end{array}$ & Cities & Total & $\begin{array}{r}\text { Counties } \\
\text { and Zagreb }\end{array}$ & $\begin{array}{r}\text { Cities and } \\
\text { municipalities }\end{array}$ & Total \\
\hline 1. & El. education & 411 & 153 & 564 & 497 & 188 & 685 \\
\hline 2. & Sec. education & 317 & 0 & 317 & 384 & 0 & 384 \\
\hline 3. & Health care & 385 & 0 & 385 & 398 & 0 & 398 \\
\hline 4. & Welfare & 245 & 0 & 245 & 260 & 0 & 260 \\
\hline \multirow[t]{2}{*}{5.} & Fire departments & 0 & 0 & 0 & 0 & 79 & 79 \\
\hline & Total obligations & 1,358 & 153 & 1,511 & 1,539 & 267 & 1,806 \\
\hline a) & $\begin{array}{l}\text { Resources from additional } \\
\text { share in income tax }\end{array}$ & 589 & 77 & 665 & 719 & 177 & 896 \\
\hline b) & Equalisation fund & 769 & 76 & 846 & 820 & 90 & 910 \\
\hline
\end{tabular}

Source: Finance Ministry of Republic of Croatia, 2004.

Total obligations for decentralised functions increased from 1.5 to 1.8 billion kuna. Most of the resources for the financing of them were provided by central government from the Equalisation Fund. Of the resources provided in total, most of them are related to financing elementary education and health care, followed by secondary education and welfare.

The distribution of resources from the Equalisation Fund and the establishment of the total liabilities (expenditure) that need to be provided for an individual local government unit for the financing of the decentralised functions assumed are determined pursuant to certain minimum financial standards. At the recommendation of the competent ministry, the Government and Ministry of finance each year sets the minimum financial standards or the cost of performing some activity. In defining minimum financial standards, the competent ministries take into consideration the differing needs for public resources of the local government units. For example, the criterion for the allocation of resources to cover material and financial expenditure in secondary schools is the number of enrolled pupils in a certain year multiplied by the average annual cost per pupil. The average annual cost is set for each individual local government unit.

Areas of special national concern and the hill and mountain regions

Since 1996 there have been three groups of areas of special national concern (ASNC) in Croatia; in them there are 180 local government units (50 in the first group, 61 in the second and 69 in the third). The first and second groups are set according to the degree of economic damage brought about by destruction during the war up to 1996. The third group is assessed according to four criteria: economic development, structural difficulties, demographic and special criteria. It has been established that all the three groups together might cover up to $15 \%$ of the total population of Croatia. For these areas, the central government regularly provides grants from the national budget. However, from 2000, additional incentive measures for areas of special national concern have been brought in. Thus revenue from income and profit tax (otherwise shared between central government and the local government unit) will be made over completely to the municipalities and cities in these areas. 
Table 12 Tax sharing in areas of special national concern (ASNC)

\begin{tabular}{|l|r|r|r|}
\hline & Central government & Counties & Cities and municipalities in ASNC \\
\hline Income tax & - & 10 & 90 \\
\hline Profit tax & - & 10 & 90 \\
\hline
\end{tabular}

Source: Finance Ministry of Republic of Croatia.

From 2002, 45 local government units acquired the status of hill and mountain areas, for the sake of encouraging faster and more even economic development. They were given the same tax incentives and tax shares as the ASNC. However, it is not clear to what extent these hill and mountain areas differ from the local government units in the ASNC. Because of powerful lobbying and the lack of any clear criteria, some municipalities and cities whose fiscal capacity enables the financing of current expenditure have nevertheless got into the hill and mountain areas. The main problem is that there has been no proper audit and it has not been determined how much the fiscal capacities of local government units in the ASNC and the hill and mountain areas have increased, and how many of these local government units there are that do not need to be in a special system of financing.

\subsubsection{Tax sharing for the financing of capital projects}

For the sake of protecting the islands and for more rapid demographic development, in 2003 the Government adopted incentive measure for the development of 45 insular local government units. These incentives were introduced in the form of preferences for the purchase or lease of agricultural land, the financing of capital projects for water and water supply, physical planning and improvement of the traffic and transportation infrastructure. The government has ceded its part of the revenue from income tax $(29.6 \%)$ only to those municipalities and cities on the islands that make joint agreements about the financing of capital projects in their area.

\subsection{Horizontal fiscal equalisation}

\subsubsection{Current grants for horizontal fiscal equalisation}

Central government allocates current grants to financially worse-off local government units with a belowaverage capacity. Between 1994 and 2001 current general grants from the national budget were allocated to counties in the area of which the revenue of all the local government units (cities and municipalities), not including the city of Zagreb, was less than $75 \%$ of the national per capita revenue. The grant was provided from the national budget, the amount being the difference between the per capita revenue realised in the county and the $75 \%$ republic average per capita revenue. This assumes that all local government units have the average tax burden. Grants cannot be allocated to counties in the area of which the rate of surtax is less than $1 \%$ and the rates of taxation and the amounts of taxation are lower than the highest rates regulated by law, or the amount of the tax. In a similar way, the counties allotted grants to the cities and municipalities in their area.

These criteria are still prescribed in the Law on financing of local government units. Unfortunately, although defined by law, these criteria were never actually used in the real calculation and definition of the criteria for the allocation of central government grants to local government units. 
From 2001 central government in the annual budget execution laws set new criteria for the allocation of current general grants. Central government allocated such grants only to counties in the area of which there are local government units (cities and municipalities) that form part of the group of local government units that belong to the ASNC. Counties must allocate at least $50 \%$ of the current general grants that they obtain from central government to cities and municipalities that do belong to ASNC. The other $50 \%$ of the resources can be allocated by the county according to its own criteria to the other cities and municipalities.

Criteria for the calculation and allocation of central government grants to counties from 2001 on were: average revenue of county budget per capita and revenue of county budget per capita of the county, average expenditure for capital programmes of the county budget per capita and expenditure for capital programmes from the country budget per capita of the county. The criteria for the calculation and distribution of grants to cities and municipalities since 2001 have been: average revenue per capita of cities and municipalities, average revenue per capita in areas of special national concern or of individual cities and municipalities in the area, share of expenditure for capital investment programmes in total expenditure, balance of material expenditure (population size and expenditure per capita), the rationality of the system (number of employees, expenditure per employee) and expenditure on the functions of the city (below 30,000 population), and a correction factor for the gradual transition to the new model of calculating grants.

In the definition of criteria for the allocation of current general grants to counties, cities and municipalities the differences in disposable revenue are taken into account (for example, revenue of a given local budget per county capita for a given year are taken into account in the criteria for the allocation of grants), as well as the different needs for public expenditure in the local government units. For example, expenditure for capital investment programmes for a given year per capita of the local government unit is included in the criteria for the allocation of grants to counties. However, the problem is that the criteria for the allocation of general grants are not fixed and or defined clearly enough. Grant allocation criteria are described but not given in numerical value; i.e. there is no strict mathematical formula.

\subsubsection{Capital grants}

Grants via the competent ministries. Capital grants are allocated to cities and municipalities that suffered war damage, natural disasters or for some given matters. These are usually grants for capital projects that last longer than one year. Local government units send applications for financing to the authorised ministries (for example, the Ministry of Public Works, Redevelopment and Construction). On behalf of the local government units, these ministries in turn forward the application to the Finance Ministry, which accepts or denies it. Unfortunately the Finance Ministry has no capital investment department to supervise the authorisation and use of capital grants.

Grants via the Regional Development Fund. Apart from via the different ministries, capital grants are also allocated via the Regional Development Fund. This Fund was founded in 2001 to encourage even regional development of areas that have a GDP lower than $65 \%$ of the Croatian mean GDP. This Fund is financed from the national budget, with revenue from privatisation, bonds, loans, donations and other sources. 
The Fund can finance up to $50 \%$ of the capital investment project of a local government unit without repayment. In this, no-repayment financing is considered particularly suitable for local government unit infrastructure projects. Depending on the importance of the infrastructure project for regional development or a given county or several counties, the Board of Management of the Fund makes a decision about the Fund's involvement. According to a cost-benefit analysis, the specific objectives of the given counties and the degree to which ecological standards are observed, the Fund (at the recommendation of the counties) will make a decision about the no-repayment financing of capital investment projects. However, the criteria for the allocation of capital grants via the Regional Development Fund are not defined clearly or in detail.

\section{THE MAIN PROBLEMS AND THE RECOMMENDATIONS}

A number of structural problems constituting a constraint on the continuation of the reforms begun in 2001 have appeared in the local government unit financing system, before and after the beginning of the process of fiscal decentralisation. For this reason in the sequel we list the main problems in the implementation of fiscal decentralisation and give recommendations for the resolution of these problems.

\subsection{The problems}

Unequal financial position of local government units. Although the number of local government units capable of financing current expenditure with current revenue has increased, there are still a larger number of local government units that are given current grants by central government. In Croatia, as many as 270 local government units (cities and municipalities) have a special status in the financing system, to which central government allows tax breaks, cedes the whole or part of the income and profit tax, and additionally provides grants for horizontal fiscal equalisation. However, the special status in the financing of these local government units must be called into question, since the number of financially independent local government units that can finance current expenditure without difficulties with current revenue has increased $^{3}$. In 2002, of the 556 municipalities and 122 cities, 380 of them (70\% of all local government units) had current revenue greater than current expenditure. In 2003 the situation improved still further and $85 \%$ of local government units are capable of financing current expenditure independently.

Regional unevenness. There are important regional inequalities in Croatia, which the Government and the Finance Ministry have taken too little into account in setting the criteria and transferring grants. In the allocation of grants, high quality calculations of fiscal capacities of all local government units have not been paid sufficient attention. In addition to this, even the tax revenue sharing model does not take into account the fiscal capacities of local government units. The city of Zagreb, which is part of the tax sharing system, can finance the decentralised functions without any problem from its own revenue. The city of Zagreb, the most powerful local government unit in financial terms, accounts for about $40 \%$ of the total budgets of all local government units, while the liquid resources of the city constitute about $45 \%$ of the liquid resources of all local government units.

The fiscal equalisation model (mechanism for allocating grants and tax sharing) is not founded on realistically determined calculations of the fiscal capacities of all the local government units. A particular

\footnotetext{
${ }^{3}$ The following receipts are excluded from operational revenue: 1 . Domestic and foreign grants, subsidies and transfers from the national budget and the budgets of other local government units and 2. From special contracts (local levies and joint financing from citizens).
} 
problem arises in the setting and calculation of the minimum standards for the decentralised functions. The criteria for the transfer of grants (current and capital) are unclear. Because there is poor coordination between the Finance Ministry and other ministries, the allocation of grants is often not done according to a realistic evaluation of the financial position of the local government units. For this reason the grants are often wrongly directed to local government units the fiscal capacity of which is greater than the average of the other local government units in Croatia.

The Regional Development Fund. The role of the Fund in the financing of the capital investment projects of local government units is questionable. Apart from allocating no-repayment capital grants, the Fund also takes part in authorising loans to local government units for the construction of municipal infrastructure at low rates of interest. The problem here is that there is no quality model for the allocation of capital grants at the level of central government, neither have any criteria been established. For this reason the founding of this Fund (which also carries out matters characteristic of a national development bank) brought additional complication into the financing of the capital projects of local government units.

Fiscal discipline. The financial position of local government units could be additionally improved if there were better fiscal discipline, or the collection of non-tax revenue (revenue according to special regulations, as it is called). In 2003 local government units had outstanding claims for almost 6 billion kuna, on the whole of non-tax revenue, and from the sale of capital assets.

Table 13 Outstanding public revenue of local government units, the state of affairs as of the end of the period, in million kuna

\begin{tabular}{|c|c|c|c|}
\hline Outstanding claims for & Balance of 2001 & Balance of 2002 & Balance of 2003 \\
\hline 1. Operational revenue & 3,273 & 3,492 & 3,879 \\
\hline - taxes & 490 & 554 & 631 \\
\hline - contributions & 1 & 8 & 2 \\
\hline - assets* & 883 & 992 & 1,084 \\
\hline - administrative fees ${ }^{* *}$ & 1,835 & 1,888 & 2,089 \\
\hline - other claims & 65 & 63 & 8 \\
\hline 2. Sale of capital assets & 2,236 & 2,182 & 2,090 \\
\hline 3. Total $(1+2)$ & 5,509 & 5,674 & 5,969 \\
\hline
\end{tabular}

Source: Consolidated finance report of local government units, Finance Ministry of Republic of Croatia, 2004.

* Revenue from assets refers to interest from loans made and securities, time deposits, dividends, revenue from profits of corporations and so on.

** Administrative fees refer to non-tax revenue mainly for municipal economy charges and contributions.

Outstanding administrative charges and revenue from interest for loans made and profit from local utility firms are increasing. Fiscal discipline is greater with respect to the taxes that the Tax Administration collects on behalf of the local government units. Although they carry out collection independently, local government units are weakest at collecting non-tax revenue.

Net financial position of local government units. In spite of resources for financing having been provided and the transfer of authorities, the implementation of fiscal decentralisation is proceeding slowly. Support for this claim is given by indicators from the analysis of the net financial position of local government units 
from 2001 to 2003. A net financial asset is the difference between financial assets and financial liabilities ${ }^{4}$ and is a useful indicator of the liquidity of local government units (see Table 14). In 2003 net financial assets with shares and equity greatly outweighed the liabilities of local government units, coming to as much as 6 billion kuna. The net financial assets not including shares and equity were weaker, and the financial assets of local government units in 2003 were 1.3 billion kuna greater than their financial liabilities.

Cash surpluses (solvency). The balance of cash deposits in accounts has increased since 2001. This increase is the result of a larger share in income tax and the introduction of surtax. The question must arise as to whether the local government units, instead of financing decentralised functions, kept resources in accounts at commercial banks. It should be pointed out that the cumulative amount of 1.7 billion kuna in the accounts of local government units held at commercial banks is almost identical to the amount of the funds that the central government allocated in the last three years from the Equalisation Fund for the purpose of financing the decentralised functions.

Investment in shares and equity. Local government units invest in shares and equity of corporations and financial institutions in and outside the public sector (see Table. 14, Financial Assets and Liabilities). The growth of such investment leads to the question of whether the local government units have used part of their budgetary surpluses and funds obtained for the decentralised functions from the Equalisation Fund for investment in financial assets. This particularly refers to the city of Zagreb and the other financially strongest local government units.

\subsection{Recommendations}

1. While calculating fiscal capacities as criterion for the allocation of grants central government should consider the possible exclusion, alongside the city of Zagreb, of other units with high fiscal capacities (Istria and Primorsko-goranska counties).

2. While fixing the amount of grants to local government units, central government should calculate the fiscal capacities of all local government units. In this, one should particularly make use of regional GDP, all per capita revenue and expenditure on the base of which the criteria should be established, and determine the amount of the grant that needs to be allocated to individual local government units.

3. Collaboration between the Finance Ministry and the other ministries should be improved in order the better to define the minimum financial standards, particularly for the decentralised functions. Setting the minimum standards must be based on joint calculations of the Finance Ministry and the competent ministries (for health care, welfare, education).

4. Assuming that the Government and the Finance Ministry in the coming period manage to lay down clear criteria for transferring capital grants and a model of financing the capital projects of local government units with poor fiscal capacity, there should be no need for the Regional Development Fund. This Fund in the future should be integrated into the Finance Ministry, as department that deals with the monitoring of

\footnotetext{
${ }^{4}$ A financial asset of local government units consists of money in the treasury, deposits, loans given, securities, stocks and shares in the capital of institutions within or without the public sector. Financial liabilities include all the liabilities of a local government unit that relate to cheques and bills issued, securities and loans assumed.
} 
capital investment at the level of central government and of local government units (an assets management department).

5. Local government units must be more responsible and improve the collection of non-tax revenue in their area.

\section{CONCLUSION}

It can be concluded that in Croatia the autonomy of local government units to set tax bases and rates is relatively restricted; this does not apply to non-tax revenue. Autonomy when determining what resources should be applied to is also partially restricted. For local government units must spend most of their resources for purposes defined by law. Still, in spite of the limited capacity to dispose of revenue and determine what expenses are for, the financial position of local government units is excellent. Since 2001, the system of tax revenue sharing and the allocation of grants provided considerable financial resources, through which the fiscal capacities of local government units were improved in a major way. Asset-derived revenue increased in the budgets of local government units, and many local government units have large resource in accounts with commercial banks.

In spite of the Government and the Finance Ministry having opted for a system of fiscal equalisation that depends on revenue sharing and the allocation of grants, there are a number of problems related to the determination of the real fiscal position of local government units, particularly the criteria for revenue sharing and the allocation of grants. In the fiscal equalisation system inadequate attention is paid to regional and fiscal inequalities at the level of local government units. One of the key problems is the poor institutional autonomy of the Finance Ministry in the setting of criteria and the poor coordination between the Finance Ministry and the competent ministries that should take part in the elaboration of the minimum financial standards and the evaluation of the expenditure of local government units.

The Government and the Finance Ministry should review the existing system of fiscal equalisation and the allocation of grants. An additional reason is that local government units channel some of the financial resources meant for the financing of the decentralised functions and fiscal equalisation into financial assets. The Government and Finance Ministry should determine whether the local government units (particularly the city of Zagreb) use the resources derived from grants for decentralised functions for investing in securities (shares and equity). After this check the criteria will need to be reviewed, as well as the way of allocating grants from the national budget for all local government units. Grants from the national budget would then be denied to local government units that through investment in shares and equity in corporations and financial institutions within or without the public sector are increasing their financial assets.

For the central government, the task remains to check the first effects of the process of fiscal decentralisation, to control much more effectively the purposes for which grants are used, and to define more appropriately the criteria for the allocation of intergovernmental budgetary grants and revenue sharing with local government units. 


\section{LITERATURE}

Bajo, A. 1999. Zašto i kako mjeriti fiskalni kapacitet lokalnih jedinica. Financijska praksa, 23 (3), 277308.

Bajo, A. 2004. Local government units borrowing in Croatia; opportunities and constraints, Newsletter of Institute of public finance, no.15 (available online on: http: www.ijf.hr/eng).

HNB. Bilteni HNB-a. Zagreb: Hrvatska narodna banka.

Ministarstvo financija. Mjesečni statistički prikazi Ministarstva financija RH. Zagreb: Ministarstvo financija RH.

Ott, K., 1996. Fiskalna regionalna i razvojna politika u kontekstu Nacionalnog programa razvitka hrvatskih otoka. Financijska praksa 20(4), 399-417.

Ott, K. and Bajo, A., 2001. «Lokalne financije i lokalni proračuni». Financijska teorija i praksa, 23 (3), $311-449$

Ott, K., Bajo, A. and Pitarević, M., 2003. Fiscal decentralization in Croatia, FDI Proceedings. Zagreb: The Fiscal Decentralization Initiative for Central and Eastern Europe: Institut za javne financije.

Pitarević, M., 2002. Decentralizacija u Republici Hrvatskoj - proračun jednoga grada od 1996. do 2000. godine. Financijska praksa, 26 (4), 775-793.

Zakon o proračunu, NN 96/03. Zagreb: Narodne novine.

Zakon o financiranju jedinica lokalne samouprave i uprave, NN 117/93, 59/01,107/01,117/01., Zagreb: Narodne novine.

Zakon o otocima, NN 34/99, Zagreb: Narodne novine.

Zakon o Vatrogastvu, NN 58/93 i 196/99, Zagreb: Narodne novine.

Zakon o područjima posebne državne skrbi, NN 44/96 and 26/03, Zagreb: Narodne novine.

Zakon o brdsko-planinskim područjima, NN 12/02, Zagreb: Narodne novine.

Zakoni o izvršavanju državnog proračuna od 1999. do 2004. godine. Zagreb: Narodne novine.

\section{List of abbreviations:}

Counties:

VS - Vukovarsko-srijemska

BP - Brodsko-posavska

ŠK - Šibensko-kninska

ZG - Zagrebačka

ZD - Zadarska

PS - Požeško-slavonska

SD - Splitsko-dalmatinska

OB - Osječko-baranjska

BB - Bjelovarsko-bilogorska

KZ - Krapinsko-zagorska

LS - Ličko-senjska

VP - Virovitičko-podravska

$M \boxminus$ - Međimurska

KA - Karlovačka 
SM - Sisačko-moslovačka

DN - Dubrovačko-neretvanska

VŽ - Varaždinska

KK - Koprivničko-križevačka

PG - Primorsko-goranska

IS - Istria

GZ - Grad Zagreb (City of Zagreb) 


\section{Annex}

Table 14 Size and structure of financial assets and obligations of local government units from 2001 to 2004, in million kuna

\begin{tabular}{|lrrr|}
\hline & 2001 & 2002 & 2003 \\
\hline a) Financial assets & $5,929.4$ & $7,104.9$ & $8,357.2$ \\
\hline Money in cash & 989.5 & $1,894.2$ & $2,001.3$ \\
Deposits, collateral & 359.8 & 360.1 & 540.9 \\
Loans issued & 505.4 & 551.8 & 676.6 \\
domestic & 502.6 & 551.0 & 676.1 \\
foreign & 2.8 & 0.8 & 0.5 \\
Securities & 126.2 & 94.9 & 90.4 \\
Shares and equity & $3,948.5$ & $4,203.9$ & $5,047.9$ \\
\hline a)1. Financial assets not inc. shares & $1,980.9$ & $2,901.0$ & $3,309.4$ \\
\hline b) Financial assets liabilities & $1,726.5$ & $1,941.3$ & $1,987.5$ \\
\hline Cheques and bills & 0.2 & 0.1 & 0.1 \\
Other securities & 3.0 & 3.0 & 0.1 \\
Loans assumed & & $1,938.3$ & $1,987.3$ \\
\hline domestic loans & $1,448.8$ & $1,666.3$ & $1,594.6$ \\
foreign loans & 274.5 & 272.0 & 392.7 \\
\hline c) Net financial position (with shares and equity) (a-b) & $4,202.8$ & $5,163.6$ & $6,369.8$ \\
\hline d) Net financial position (not inc. shares and equity) (a.1.-b) & 254.4 & 959.7 & $1,321.9$ \\
\hline
\end{tabular}

Source: Consolidated financial report of local government, Finance Ministry of Republic of Croatia , 2004.

Table 15 Total local government revenue with and without central government grants in 2001, in kuna

\begin{tabular}{|l|c|r|r|}
\hline Counties & Abb. & Revenue per capita & $\begin{array}{r}\text { Total revenue (revenue+grants) } \\
\text { per capita }\end{array}$ \\
\hline Brodsko- posavska & BP & 701 & 898 \\
\hline Vukovarsko- srijemska & VS & 805 & 1,166 \\
\hline Požeško- slavonska & PS & 814 & 1,174 \\
\hline Krapinsko-zagorska & KZ & 859 & 1,225 \\
\hline Virovitičko-podravska & VP & 871 & 1,237 \\
\hline Međimurska & MĐ & 975 & 1,203 \\
\hline Bjelovarsko-bilogorska & BB & 985 & 1,301 \\
\hline Osječko-baranjska & OB & 1,121 & 1,373 \\
\hline Varaždinska & VŽ & 1,162 & 1,362 \\
\hline Šibensko-kninska & ŠK & 1,186 & 1,628 \\
\hline Karlovačka & KA & 1,218 & 1,627 \\
\hline Koprivničko-križevačka & KK & 1,395 & 1,645 \\
\hline Sisačko-moslovačka & SM & 1,462 & 1,855 \\
\hline Zagrebačka & ZG & 1,503 & 1,661 \\
\hline Ličko-senjska & LS & 1,519 & 2,148 \\
\hline Zadarska & ZD & 1,660 & 1,988 \\
\hline
\end{tabular}




\begin{tabular}{|l|c|r|r|}
\hline Dubrovačko-neretvanska & DN & 1,748 & 2,130 \\
\hline Splitsko-dalmatinska & SD & 1,815 & 1,963 \\
\hline Primorsko-goranska & PG & 3,154 & 3,302 \\
\hline Istarska & IS & 3,388 & 3,568 \\
\hline Grad Zagreb & GZ & 4,264 & 4,264 \\
\hline Total average & & $\mathbf{2 , 0 2 9}$ & $\mathbf{2 , 2 4 5}$ \\
\hline Total average without Grad Zagreb & & $\mathbf{1 , 5 5 2}$ & $\mathbf{1 , 8 1 5}$ \\
\hline
\end{tabular}




\section{INSTITUTE OF PUBLIC FINANCE - OCCASIONAL PAPER SERIES}

No. 1 State Intervention for Growth Promotion in Market Economies

Marina Kesner Škreb, January 1997

No. 2 Estimate of Revenues from the Value Added Tax in the Republic of Croatia

Danijela Kuliš and Žarko Miljenović, October 1997

No. 3 The Unofficial Economy in Croatia: Causes, Size and Consequences

Ivo Bićanić and Katarina Ott, November 1997

No. 4 Price Effects of VAT Introduction in Croatia

Martina Dalić, December 1997

No. 5 Tax Administration Reform in Transition: The Case of Croatia

Katarina Ott, April 1998

No. 6 The Present Sate of the Croatian Public Debt

Zoran Bubaš, December 1998

No. $7 \quad$ Public Investment in Croatia

Katarina Ott and Anto Bajo, March 1999.

No. 8 Welfare Policy and Social Transfers in Croatia

Predrag Bejaković and Alastair McAuley, July 1999

No. 9 Is Unofficial Economy a Source of Corruption?

Vedran Šošić and Michael Faulend, November 1999

No. 10 Banking Sector Problems: Causes, Resolutions and Consequences

Ljubinko Jankov, March 2000

No. 11 Toward a Long - Term Strategy of Economic Development of Croatia: Where to Begin, What to Do, and How to Do It?

Dubravko Mihaljek, June 2001

No. 12 The Underground Economy in Croatia

Katarina Ott, March 2002

No. 13 An Estimate of the Extent of Tax Evasion in Croatia

Sanja Madžarević Šujster, April 2002

No. 14 Opportunism, Institutions and Moral Costs: The Socio - Cultural Dimension of the Underground Economy in Croatia 1995 - 1999

Aleksandar Štulhofer and Ivan Rimac, April 2002

No. 15 Dollarisation and the Underground Economy: Accidental Partners?

Vedran Šošić and Michael Faulend, April 2002 
No. 16 Decentralization in the Republic of Croatia - A City Budget in the Period from 1996 to 2000

Mihaela Pitarević, March 2003

No. 17 Inequality in Croatia in the Period from 1973 to 1998

Danijeli Nestić, April 2003

No. 18 State Aid to Enterprises in Croatia in 2001

Marina Kesner-Škreb, Ivana Pleše and Mia Mikić, October 2003

No. 19 The Role of Parliament in the Budgetary Process - The Example of the Croatian Parliament (2000-2003)

Vjekoslav Bratić, October 2004

No. 20 Local Government Unit Borrowing in Croatia: Opportunities and Constraints Anto Bajo, October 2004

No. 21 The costs of customs compliance in Croatia in 2001

Mihaela Bronić, November 2004

No. 22 Tax compliance costs of small business in Croatia

Helena Blažić, November 2004

No. 23 The compliance costs of excise duties in Croatia

Danijela Kuliš, November 2004

No. 24 The administrative costs of taxation and customs clearing in Croatia, 1999-2001 Vjekoslav Bratić and Mihaela Bronić, November 2004

No. 25 Fiscal decentralisation in Croatia - problems of fiscal equalisation

Anto Bajo and Mihaela Bronić, May 2005 